Статья с открытым доступом под лицензией CC BY-NC-ND (https://creativecommons.org/licenses/by-nc-nd/3.0/) Материалы Международной практической интернет-конференции «Актуальные проблемы науки»

Выпуск II, ноябрь 2019

ISBN 978-601-323-144-0

https://doi.org/10.31643/2019.022

Айткенова Гульжанат Толеутаевна

РГП на ПХВ«Республиканский научно-исследовательский

институт поохране труда Министерства труда

и социальной защиты населения»

Старший научный сотрудник

лаборатоии профессиональных рисков

г.Нур-Султан, Казахстан E-mail: nauka@ rniiot.kz

ORCID ID: 0000-0001-5543-0997

\title{
Разработка интегрированной системы управления охраной труда на преприятии транспортной отрасли
}

\begin{abstract}
Абстракт: Интегрированная система управления охраной труда на основе управления профессиональными рисками является составной частью системы управления производством, определяет единый порядок подготовки, принятия и реализации решений по осуществлению организационных, технических и санитарно-профилактических мероприятий, направленных на обеспечение безопасных и здоровых условий труда на предприятий. Функции интегрированной системы управления охраной труда на основе профессиональными рисками - это часть процесса управления производством на предприятий. В настоящей работе представлены результаты апробации разработанной интегрированной системы управления охраной труда на примере одного из предприятий транспортной отрасли, которое относится к компоненту воздушного транспорта Республики Казахстан. Полученные результаты могут использоваться на отечественных транспортных предприятиях, и ожидается положительный эффект в регулировании трудовых отношений.
\end{abstract}

Ключевые слова: система управления охраной труда, безопасность труда, оценка профессиональных рисков, условия труда.

Принципами трудового законодательства Республики Казахстан являются обеспечение права на условия труда, отвечающие требованиям безопасности и гигиены, приоритет жизни и здоровья работника и государственное регулирование вопросов безопасности и охраны труда [1].

«Система управления охраной труда» - комплекс взаимосвязанных мероприятий по реализации политики охраны труда, выполнению требований безопасности труда, управлению профессиональными рисками.

При разработке системы управления охраной труда для транспортных предприятий следует обратить внимание специфику транспортных услуг предприятия, в зависимости от категории транспортных средств и их специального назначения. Это отражается на организации работы по охране труда, ведь специальная техника требует дополнительных навыков работы и профессиональной подготовки. При перевозке пассажиров и грузов также необходимо уделять особое внимание подбору кадров. Особые требования к работникам, связанным с движением 
транспортных средств, закреплены в статьях 48, 184 и 186 Трудового кодекса Республики Казахстан от 23.11.2015 года. Они касаются отстранения от работы в случае нарушении правил охраны труда, безопасности рабочих мест и расследования и учет несчастных случаев, связанных с трудовой деятельностью.

Вместе с тем, в Законе РК «О транспорте в Республике Казахстан» от 21.09.1994 года № 156XIII приведены требования профессиональной подготовки и состояния здоровья, которые необходимы для выполнения должностных обязанностей (статья 16. Право управления транспортными средствами). При приеме на работу такой сотрудник должен предоставить документы, подтверждающие уровень его профессиональной подготовки. Их перечень зависит от должностных обязанностей. Это могут быть водительское удостоверение определенной категории, право на перевозку опасных грузов, право на управление спецтехникой и др. Обязательно предъявляется медицинская справка о пригодности к выполнению работ, связанных с управлением транспортным средством.

Согласно статьи 23 (Обеспечение безопасности и экологических норм на транспорте), Закона «О транспорте в Республике Казахстан» территории метрополитена, станций, портов, пристаней, аэропортов, транспортных предприятий и железнодорожных линий, а также водные пути, на которых осуществляются движение транспортных средств и погрузочно-разгрузочные работы, являются зонами повышенной опасности. Правила нахождения в зоне повышенной опасности и проведения в ней работ утверждаются уполномоченным государственным органом. В настоящий момент в Республике Казахстан действуют Правила нахождения в зоне повышенной опасности метрополитена и проведения в ней работ (Постановление акимата города Алматы от 19.03.2015 года N 1/176).

Для дальнейшего снижения уровня производственного травматизма и улучшения условий труда работников занятых во вредных условиях труда в соответствии с международными нормами, РГКП «Республиканский научно-исследовательский институт по охране труда Министерства труда и социальной защиты населения Республики Казахстан» в рамках научно-технической программы проводит научно-исследовательскую работу по «Разработке научно-методических основ обеспечения безопасного труда в приоритетных секторах экономики Республики Казахстан».

При проведении научно-исследовательской работы, была анализирована действующая система управления охраной труда и апробирована разработанная Институтом интегрированная система управления охраной труда более чем на 15 предприятиях различных отраслей, форм собственности и управления, в частности на предприятиях транспортной отрасли.

Анализ на соответствие международным требованиям показал, что все нормы в той или иной степени выполняются.

Система управления охраной труда в Республике Казахстан должна перейти от компенсационной, затратной модели, основанной на выплатах за утраченное здоровье, к современной системе оценки и управления профессиональными рисками.

Необходимо создать систему оценки качества каждого рабочего места, которая нужна для того, чтобы:

- выявлять реальное вредное воздействие на каждом конкретном рабочем месте;

- устанавливать гарантии за вредные условия труда персонально для каждого работника;

- избавить работодателя от выплат компенсаций, если он обеспечил благоприятные и безопасные условия труда.

Система должна быть независимой, профессиональной и компетентной.

В настоящей статье представлены результаты апробации методики на примере одного из предприятий транспортной отрасли, которое относится к компоненту воздушного транспорта.

Предприятие относится к субъектам среднего предпринимательства. Общая численность работников по штатному расписанию составляет 168 человек. Профессионально-квалификационная структура предприятия состоит из 72 профессий. От общей численности работников $74 \%$ занимают работники основного производственного персонала, 8\% административный персонал и $18 \%$ вспомогательный производственный персонал. Между тем, необходимо отметить, что в данном предприятии отсутствовали оценки профессиональных рисков и система управления охраной труда.

Интегрированная системы управления охраной труда на основе управления профессиональными рисками (ИСУОТ на основе УПР) является составной частью системы управления производством, определяет единый порядок подготовки, принятия и реализации решений по осуществлению организационных, технических и санитарно-профилактических мероприятий, направленных на обеспечение безопасных и здоровых условий труда. 


\begin{tabular}{|c|c|c|}
\hline $\begin{array}{c}\text { Разработанные документы ИСУОТ } \\
\text { на основе УПР }\end{array}$ & $\begin{array}{l}\text { ИСУОТ на основе УПР } \\
\text { предусматривает: }\end{array}$ & Элементы СУОТ \\
\hline $\begin{array}{l}\text { - Политику в области охраны } \\
\text { труда; } \\
\text { - Результаты оценки } \\
\text { профессиональных рисков; } \\
\text { - Методические рекомендации по } \\
\text { оценке профессиональных рисков; } \\
\text { - Порядок проведения аттестации } \\
\text { производственных объектов по } \\
\text { условиям труда; } \\
\text { - Положение об обеспечении } \\
\text { работников специальной одеждой, } \\
\text { специальной обувью и средствами } \\
\text { индивидуальной защиты; } \\
\text { - Положение о порядке } \\
\text { проведения обучения } \\
\text { (переподготовки), } \\
\text { инструктирования проверки } \\
\text { знаний по вопросам безопасности } \\
\text { и охраны труда; } \\
\text { - Положение об организации } \\
\text { проведения обязательных } \\
\text { медицинских осмотров; } \\
\text { - Порядок оповещения и } \\
\text { дасследования несчастных } \\
\text { деятельностью. }\end{array}$ & 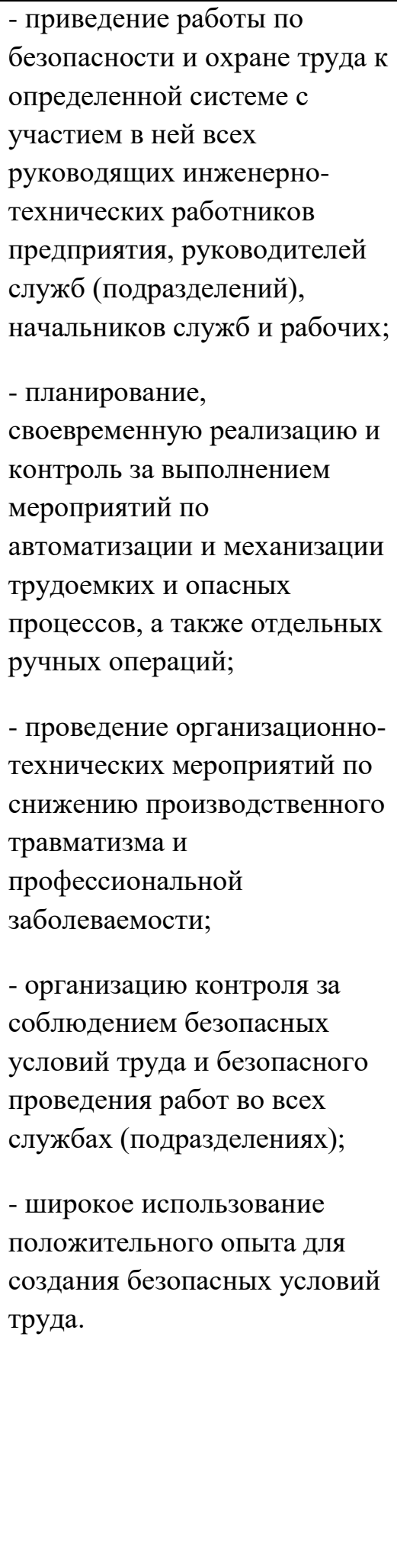 & $\begin{array}{l}\text { Функции ИСУОТ на } \\
\text { основе УПР - это часть } \\
\text { процесса управления } \\
\text { производством, } \\
\text { направленная на } \\
\text { организацию, обеспечение } \\
\text { и координацию работ в } \\
\text { области безопасности и } \\
\text { охраны труда, которые } \\
\text { содержат следующие } \\
\text { элементы: } \\
\text { - четкое распределение } \\
\text { функций, обязанностей, } \\
\text { прав и ответственности в } \\
\text { области безопасности и } \\
\text { охраны труда; } \\
\text { дезопасности и охране } \\
\text { труда. } \\
\text { другой нормативной } \\
\text { документации по } \\
\text { вействующихущая и } \\
\text { координирующая роль } \\
\text { службы безопасности и } \\
\text { охраны труда в } \\
\text { функционировании и } \\
\text { совершенствовании } \\
\text { системы управления } \\
\text { охраной труда, } \\
\text { планировании ее } \\
\text { эффективности и ее } \\
\text { контроле; } \\
\text { - обеспечение выполнения } \\
\text { планов мероприятий по } \\
\text { безопасности и охране } \\
\text { труда; } \\
\text { обеспечение выполнения } \\
\text { осебований правил, } \\
\text { олартов и }\end{array}$ \\
\hline
\end{tabular}

Управлению подлежит деятельность всех служб (подразделений) ТОО по обеспечению безопасных условий труда, соблюдение правил техники безопасности при проведении работ. Вся организационно-техническая работа по созданию здоровых и безопасных условий труда возлагается: - по ТОО - на инспектора по охране труда, технике безопасности и экологии; 
- в службах (подразделениях) - на руководителей этих служб (подразделений).

Функции ИСУОТ на основе УПР - это часть процесса управления производством, направленная на организацию, обеспечение и координацию работ в области безопасности и охраны труда, которые содержат следующие элементы:

- четкое распределение функций, обязанностей, прав и ответственности в области безопасности и охраны труда;

- организующая и координирующая роль службы безопасности и охраны труда в функционировании и совершенствовании системы управления охраной труда, планировании ее эффективности и ее контроле;

- обеспечение выполнения планов мероприятий по безопасности и охране труда;

- обеспечение выполнения всех требований правил, действующих стандартов и другой нормативной документации по безопасности и охране труда.

Выполнение требований ИСУОТ на основе УПР является должностной обязанностью всех руководителей, начальников служб и инженерно-технических работников.

Организационно-методическое руководство и координация деятельности служб (подразделений) по созданию здоровых и безопасных условий труда, постоянное совершенствование, а также контроль за выполнением требований по безопасности и охраны труда возлагается на заместителя первого руководителя.

Построение эффективной интегрированной системы управления охраной труда на предприятии способствует снижению затрат и положительным образом влияет на мотивацию сотрудников, тем самым влияет на повышение производительности и прибыльности предприятия. Вместе с тем, ИСУОТ помогает значительно сократить издержки, при этом сформировать более продуктивный рабочий климат, повысить эффективность работы, снижается текучесть кадров, улучшить имидж предприятия и обеспечить дополнительные финансовые и конкурентные преимущества.

Совершенствование культуры безопасности означает не только устранение вредных и опасных факторов на рабочем месте, это также означает серьезную работу с работниками, изменение их отношения к вопросам безопасности в области охраны труда.

\author{
Aitkenova Gulzhanat Toleutaevna \\ «Republican Research Institute for Labor \\ Protection, Ministry of Labor and Social \\ Protection of the Population of the Republic \\ of Kazakhstan», Nur-Sultan, Kazakhstan. \\ E-mail: nauka@rniiot.kz \\ ORCID ID:0000-0001-5543-0997
}

\title{
Development of an integrated labor protection management system at a transport industry enterprise
}

\begin{abstract}
An integrated labor protection management system based on occupational risk management is an integral part of the production management system and defines a unified procedure for the preparation, adoption and implementation of decisions on the implementation of organizational, technical and sanitary-preventive measures aimed at ensuring safe and healthy working conditions for enterprises. The functions of an integrated labor protection management system based on professional risks are part of the process of managing production at enterprises. This paper presents the results of testing the developed integrated labor protection management system as an example of one of the enterprises in the transport industry, which relates to the air transport component of the Republic of Kazakhstan. The results can be used at domestic transport enterprises, and a positive effect is expected in the regulation of labor relations.
\end{abstract} conditions.

Keywords: labor protection management system, labor safety, occupational risk assessment, working 
Ссылка на данную статью: Айткенова Г. (2019), Разработка интегрированной системы управления охраной труда на преприятии транспротной отрасли. Материалы Международной практической интернет-конференции «Актуальные проблемы науки» / Materials of International Practical Internet Conference "Challenges of Science". ISBN 978 601-323-144-0. Выпуск II, 2019. Стр.: 110-114. https://doi.org/10.31643/2019.022

\section{Список использованной литературы}

[1] Законе РК «О транспорте в Республике Казахстан» от 21.09 .1994 года № 156 XIII.https://online.zakon.kz/document/?doc_id=1003161

[2] Нормы выдачи специальной одежды и других средств индивидуальной защиты работникам организаций различных видов экономической деятельности, утвержденные Приказом Министра здравоохранения и социального развития Республики Казахстан от 8 декабря 2015 года № 943. http://adilet.zan.kz/rus/docs/V1500012627

[3] Конвенция МОТ №187 «Об основах, содействующих безопасности и гигиене труда», Женева, 2006 год, ЗРК от 20 октября 2014 года № 243-V ЗРК;

[4] Правила и сроки проведения обучения, инструктирования и проверок знаний по вопросам безопасности и охраны труда работников, утвержденные Приказом Министра здравоохранения и социального развития Республики Казахстан от 25 декабря 2015 года №1019;

[5] Правила разработки, утверждения и пересмотра инструкции по безопасности и охране труда работодателем утвержденные Приказом Министра здравоохранения и социального развития Республики Казахстан от 30 ноября 2015 года № 927;

[6] Правила обязательной периодической аттестации производственных объектов по условиям труда, утвержденные Приказом Министра здравоохранения и социального развития Республики Казахстан от 28 декабря 2015 года № 1057;

[7] Правила проведения обязательных медицинских осмотров Приказ и.о.Министра национальной экономики РК от 24 февраля 2015 г. №128, утвержденные Приказом Министра здравоохранения и социального развития РК от 28 декабря 2015 года № 1055;

[8] Правила выдачи специальной одежды и других средств индивидуальной защиты, утвержденные Приказом Министра здравоохранения и социального развития РК от 28 декабря 2015 года № 1054;

[9] Постановление акимата города Алматы от 19.03.2015 года N 1/176

[10] Типовое положение о службе безопасности и охраны труда в организации, утвержденные Приказом Министра здравоохранения и социального развития Республики Казахстан от 25 декабря 2015 года № 1020;

[11] Трудовой кодекс Республики Казахстан от 23 ноября 2015г.; 